Artigo Original

\title{
Nutrition and self-care practices of patients with chronic metabolic syndrome: a qualitative study*
}

\author{
Práticas alimentares e autocuidado de pacientes com Síndrome Metabólica: um estudo qualitativo \\ Los hábitos de alimentación y el autocuidado de los pacientes con Síndrome Metabólico: un estudio \\ cualitativo
}

\author{
Carla Maria Vieira ${ }^{1}$, Vera Lúcia Soares Chvatal $^{2}$, Silvia Nogueira Cordeiroº \\ Egberto Ribeiro Turato ${ }^{4}$
}

\begin{abstract}
Objective: To analyze subjective aspects of eating habits and self-care of patients living with chronic symptoms linked to metabolic syndrome. Methods: A clinical and qualitative (exploratory, non-experimental) study, conducted with an intentionally small sample of nine patients in treatment at an outpatient endocrinology clinic of a university hospital in São Paulo, Brazil. The sample was closed when data saturation occurred. The in-depth interviews were conducted with a psychodynamic orientation toward the conduct of dialogues. The categorization of the discourse was developed through content analysis. The psychodynamic approach provided a theoretical reference complemented by social anthropology. Results: Eating habits have been revealed as mediators of autonomy and as a source of vulnerability in the process of coping with chronic illness. Reception and understanding of the psychological and cultural aspects of food are needed in treatment faced with the difficulty of establishing changes in eating behavior. Conclusion: This is a contribution of an interdisciplinary approach that values listening subjectivity during treatment. Keywords: Self care; Food habits; Chronic disease; Health promotion; Metabolic syndrome; Qualitative research
\end{abstract}

\section{RESUMO}

Objetivo: Analisar aspectos subjetivos das práticas alimentares e autocuidado de pacientes na convivência com os sintomas crônicos vinculados à Síndrome Metabólica. Métodos: Estudo clínico-qualitativo (exploratório, não-experimental), realizado com amostra propositalmente pequena de nove pacientes em tratamento ambulatorial de endocrinologia em hospital universitário do Estado de São Paulo, Brasil. O grupo foi fechado por saturação de dados. As entrevistas foram realizadas em profundidade, com orientação psicodinâmica na condução dos diálogos. A categorização do discurso foi desenvolvida por meio da análise de conteúdo. A abordagem psicodinâmica foi a referencial teórico complementada pela antropologia social. Resultados: Práticas alimentares revelaram-se como mediadoras de autonomia e como fonte de vulnerabilidade na convivência com o processo de adoecimento crônico. Acolhimento e compreensão dos aspectos psicológicos e culturais da alimentação são necessários no tratamento diante das dificuldades para estabelecer mudanças no comportamento alimentar. Conclusão: Trata-se de uma contribuição de abordagem interdisciplinar, que valoriza a escuta de subjetividades no tratamento. Descritores: Autocuidado; Hábitos alimentares; Doença crônica; Síndrome X metabólica; Pesquisa qualitativa

\section{RESUMEN:}

Objetivo: Analizar aspectos subjetivos de las prácticas alimenticias y el autocuidado de pacientes en la convivencia con los síntomas crónicos vinculados al Síndrome Metabólico. Métodos: Estudio clínico-cualitativo (exploratorio, no-experimental), realizado con una muestra propositalmente pequeña de nueve pacientes en tratamiento ambulatorio de endocrinología en un hospital universitario del Estado de Sao Paulo, Brasil. El grupo fue determinado por saturación de datos. Las entrevistas fueron realizadas a profundidad, con orientación psicodinámica en la conducción de los diálogos. La categorización del discurso fue desarrollado por medio del análisis de contenido. El abordaje psicodinámico fue el referencial teórico complementado por la antropología social. Resultados: Las prácticas alimenticias se revelaron como mediadoras de la autonomía y como fuente de vulnerabilidad en la convivencia con el proceso de sufrimiento crónico. La acogida y comprensión de los aspectos psicológicos y culturales de la alimentación son necesarios en el tratamiento frente a las dificultades para establecer cambios en el comportamiento alimenticio. Conclusión: Se trata de una contribución de abordaje interdisciplinario, que valoriza la escucha de subjetividades en el tratamiento. Descriptores: Autocuidado; Hábitos alimenticios; Enfermedad crónica; Síndrome metabólico; Investigación cualitativa

* A study extracted from the doctoral thesis entitled: "Psychological and cultural meanings of the feeding behavior of sickened by chronic metabolic syndrome: a clinicalqualitative study". Study Site: Universidade Estadual de Campinas (SP), Brazil no Departamento de Psicologia Médica e Psiquiatria da Faculdade de Ciências Médicas. ${ }^{1}$ PhD. Researcher Laboratory of Clinical-Qualitative Research, Department of Medical Psychology and Psychiatry, Faculty of Medical Sciences, Universidade Estadual de Campinas - UNICAMP - Campinas (SP), Brazil, PhD in Nutrition, Universidade Metodista de Piracicaba - UNIMEP - Piracicaba (SP), Brazil. ${ }^{2} \mathrm{PhD}$ researcher at the Laboratory of Clinical-Qualitative Research, Department of Medical Psychology and Psychiatry, Faculty of Medical Sciences, Universidade Estadual de Campinas - UNICAMP - Campinas (SP), Brazil.

${ }^{3}$ PhD researcher at the Laboratory of Clinical-Qualitative Research, Department of Medical Psychology and Psychiatry, Faculty of Medical Sciences, Universidade Estadual de Campinas - UNICAMP - Campinas (SP), Brazil.

${ }^{4}$ Full Professor in Practice of Sciences, Department of Medical Psychology andPsychiatry, Faculty of Medical Sciences, Universidade Estadual de Campinas, Coordinator of the Laboratory Clinical-Qualitative Research, Campinas (SP), Brazil.

Autor Correspondente: Carla Maria Vieira

Rua Petrópolis, 219/315 - San Conrado - Sousas CEP 13104150 - Campinas - SP.

Artigo recebido em 13/01/2011 e aprovado em 25/01/2012

E-mail: cmvieira@unimep.br; carlmari@fcm.unicamp.br 


\section{INTRODUCTION}

Metabolic Syndrome (MS) has been referred to as being a group of clinical manifestations of type II Diabetes, hypertension and obesity, among other associated metabolic symptoms ${ }^{(1)}$. Conceptual differences are evidenced by several authors, which, in part, make epidemiological delimitation more difficult. There is, however, consensus about the increased prevalence of these associated symptoms among the adult population in several countries ${ }^{(2-4)}$.

International organizations debate about MS and disagree about the need to establish broad prevention measures ${ }^{(1)}$. There are also recommendations for interdisciplinary clinical practice for MS, combining contributions from different fields of knowledge in the development of specific actions for the treatment and broader public policies ${ }^{(5,6)}$.

Several authors agree that it is possible to reduce the risk for severe cardiovascular events and even suspend the continuous use of some medications if individuals give up smoking, lead a less sedentary life, along with following a balanced diet. Self care behavior has been encouraged as a therapy for individuals with chronic metabolic disorders ${ }^{(1,3)}$.

Lifestyle changes, especially eating habits and sedentary life are extensively disseminated as a health protection measure ${ }^{(7)}$. However, there is low adhesion to the health promotion proposals for self care ${ }^{(8-11)}$.

To comprehend the patients' low ability of adhesion to the self care attitudes proposed by health care professionals, especially in terms of eating, it is necessary to surpass the frontiers of medical knowledge. Understanding the process of patient adhesion to the behavior changes proposed in health practices implies to look at understanding human behavior and subjectivity, among other psychological and cultural issues ${ }^{(8,12)}$. Health teams that seek to expand clinical practice have the challenge to improve the patients' ability of psychological adapta- tion and development to achieve autonomy in everyday care management ${ }^{(13)}$.

Considering these questions, the objective of the present study was to analyze the subjective aspects of the personal experience of patients living with chronic illness due to MS and under treatment at an outpatient clinic. From this broader objective, a selection was made of some experiences reported by the patients, which were related to the process of managing treatment and eating behavior, implied in chronic metabolic disorders.

\section{METHODS}

This study had a clinical-qualitative design. Thus, a humanistic model in seeking to scientifically interpret the meanings that individuals' life experiences acquire, considering these persons' natural settings, is adopted. Hence, the present work had an exploratory, nonexperimental character.

The data collection instrument in the present research was the so-called semi directed interview with open-ended questions ${ }^{(14)}$. This approach aimed to ensure that the matter was discussed with the interviewees in depth. It has been proved to be appropriate for qualitative research within the field of healthcare, as shown in the literature ${ }^{(15,16)}$.

The study sample consisted of nine patients with metabolic syndrome (Chart 1). It was closed at this number by utilizing the saturation criterion ${ }^{(17)}$. The transcriptions from the interviews formed the corpus for the study and were subjected to qualitative content analysis. Free-floating readings of the interviewees' responses had been made, so that the researchers would be able to familiarize themselves with the material ${ }^{(17)}$.

The interviews were conducted with patients of the Endocrinology Ambulatory of the University Hospital of Campinas, in the Southwest of Brazil. The criteria established for selecting patients were: confirmed diagnosis of metabolic syndrome by the respective medical

Chart 1. Characterization of the subjects interviewed: socio demographic date and nutritional status. Campinas-SP, Brazil, 2006-2008

\begin{tabular}{|llllll|}
\hline Subjects & $\begin{array}{l}\text { Age } \\
\text { (years old) }\end{array}$ & $\begin{array}{l}\text { Marital } \\
\text { situation }\end{array}$ & Current occupation & $\begin{array}{l}\text { Time registered for } \\
\text { treatment in hospital }\end{array}$ & Nutritional state \\
\hline A & 48 & married & Housewife & 2 years & Obesity \\
\hline B & 63 & married & Maid & 10 years & Overweight \\
\hline C & 45 & married & Agricultural activity & 7 years & Obesity \\
\hline D & 48 & married & Unemployed & 4 years & Obesity \\
\hline F & 53 & married & Housewife & 6 years & Obesity \\
\hline G & 37 & married & Housewife & 13 years & Obesity \\
\hline H & 49 & divorced & Housewife, & 11 years & Obesity \\
\hline I & 55 & married & Pensioner, & 6 years & Obesity \\
\hline
\end{tabular}


team; clinical, emotional and intellectual conditions to the research interview; agreement to their participation, expressed through a statement declaring their free and informed consent, in accordance with the approval for the study granted by the Ethics Committee of the Institution (process number 809/2005 CAAE1738.0.146.00005). The following criteria were not used for patient inclusion/exclusion: gender, age, origin, marital status, family composition, educational level, socioeconomic status and religion.

After applying the categorization strategy, the categories for this study were selected. The topics thus delineated in the present study were discussed and interpreted according to psychodynamic concepts ${ }^{(18)}$. The theoretical framework encloses an interdisciplinary approach in health, in which there are psychologists, psychoanalysts and health professionals to understand and manage medical matters, such as difficulties in health professionals-patient relationship.

\section{RESULTS}

\section{Diet is a matter of opinion}

The subjects were happy to reveal their ability to establish adaptations to their eating behaviors. They consider that reducing the use of medication and controlling the symptoms were results of their active position in view of the evolution of the process of becoming ill.

My diabetes was always high... The doctor told me what I was supposed to eat... I did what she said... I took the medications. The diabetes improved! The vision problem was gone. $(\mathrm{H}, 0$,, $55 \mathrm{y})$

I took medications for two years... They suspended. Not eating sweets is good for me... eating candies all the time, I'll get diabetes. I don't have diabetes! (B, $9,63 \mathrm{y})$

Patients present themselves as subjects of their treatment and feel proud for being able to control the clinical manifestations of diabetes, for instance, which is one of the most common diseases among individuals with MS. The consistent self-esteem can be recognized as an element that promotes this active position.

I get good results from the treatment... I walk... I try to balance my diet... I take good care of myself... I enjoy living. I am 62 years old and I want to live longer $(\mathrm{B},+9,63 \mathrm{y})$

Diet is a matter of opinion. If you lose the opinion, the motivation... the treatment... it is all useless, worth nothing... (E, o, 53y)

The meanings of "opinion" and "motivation" linked to the diet, in this case, indicate that the changes in eating behaviors depend on the patients' development of internal resources. The degree of autonomy to establish adaptations to eating behaviors, useful for promoting self care and the patients' well-being, therefore, are linked to their ability to think about and develop self-esteem.

\section{My favorite place is my bed or my sofa}

The subjective aspects identified in the study suggest that poor self-esteem is related to the individual's lack of ability to analyze emotional conflicts. The subjects in this situation presented themselves as victims of the circumstances, assuming a motionless and passive position when facing the everyday barriers in the process of becoming chronically ill by MS.

I lost... my will to live... My favorite place is my bed or my sofa... That is all my life is about. $(\mathrm{G},+, 49 \mathrm{y})$

Reading in-between the lines of the roll of complaints related to the subjects' process of living with the worsening of their symptoms reveals a feeling of self-pity, a feeling that does not permit the subject to establish an active position in managing the treatment.

The bealth problem always gets worse... the back... kidney problems... the blood pressure is always high. And the bone problems... arthritis, knee osteoarthritis (E, ㅇ, 53y)

I spend my life sitting on an armchair. I'm too weak to walk, too weak to go down the stairs, too weak to go up... (A, o , 48y)

The subjects' statements of distress and physical limitations related to the feeling of self-pity were not restricted to the content of their reports. Body elements that suggest self-pity were also identified during the interviews:

I take insulin three times a day... on the leg (shows leg)... I can't take any more shots on my belly... with time the mass grows... It stays purple all over, ob! ( $\mathrm{G}, 9,49 \mathrm{y})$

The physical and emotional distress associated to the prolonged insulin use should not be minimized. However, a certain attachment to body marcs configured an attempt to show powerlessness in view of the worsening of chronic disease symptoms. The look focused on physical limitations often masks the emotional fragileness that makes it more difficult for subjects to achieve resources to overcome everyday hardships.

\section{Eating is very good}

The search for losing the excessive weight, in the MS treatment, requires patients to be autonomous to establish adaptations to their eating behaviors. It was identified that subjects who reported having poor autonomy related to food believe in an outer solution, because they do not see themselves as capable of dealing with the difficulties implied in changing their eating behavior toward self care.

... I do everything (smile)... to see if I can get a stomach reduction, because... I've tried to get on a diet but... I didn't get anywhere $(\mathrm{F}, 9,37 \mathrm{y})$.

Among the difficulties regarding food, there was emphasis on the loss of liberty and pleasure to eat. Subjects regret the losses and report feeling unmotivated to follow the prescribed diet.

You get used to... not eating this, and that... you have to cut everything... I feel sadder because I can't lose weight. Even on a $\operatorname{diet}(\mathrm{F}, \mathrm{O}, 37 \mathrm{y})$. 
I practically live for the water I drink... I used to enjoy reading recipes, to try them. Now I lost the pleasure in that $(\mathrm{A},+, 48 \mathrm{y})$.

Subjects do not feel free to savor the pleasure of eating, and report feeling guilty for breaking diet rules. In this situation, they are imprisoned by the difficulty to establish positive attitudes and seek creative adaptations to their eating behaviors that would be more adequate to the process of living with a chronic illness.

The test already made me sad... (silence and looking down) then I go to the back of the cafeteria... I ate two snacks, I had soda... I get really nervous. Because one thing improves and the other gets worse... I didn't lose weight! ( $\mathrm{G}$,, , 49y).

However, when subjects are not imprisoned to prescriptions and restrictions, eating can gain new meanings. Discovering the pleasure of eating foods in a way that is in line with self care demands, the admiration by how family members and friends prepare their food, permeated by dialogue and affection are forms of bringing new meanings to eating behaviors.

In the beginning it was very diffcult... I enjoyed eating... Eating is very good! But with time I started seeing I couldn't ( $\mathrm{B}$, , +, 63y).

People... like how I prepare my food... I really like cooking... I enjoy making... feijoada... in a lighter way... I go to a barbecue with my friends... I take my beverage... I spend Christmas at my mother's house... big family... we decide about which plate each one will prepare (B, + , 63y).

To overcome the loss of pleasure and liberty in eating, individuals must assume the position of subjects of their own history. In this way, it is possible for them to discover new meanings related to eating, which will collaborate to manage diet prescriptions and live with the self care demands required by the process of becoming chronically ill.

\section{It could have been better if there was com- prehension from my mother and father}

The ability to establish self care behaviors in eating is associates with the emotional development marked by significant experiences in one's life history. Eating behaviors are often a means for expressing these issues, which appear in the form that patients develop their ability for self-protection and managing self care demands.

When a child is molested by an adult, like I was... I was 5 years old... until I was $11 \ldots$ it was exactly at that time... that I started gaining weight... it could have been better if there was understanding from my mother, my father (I, q, 54y).

Some patients develop active positions, and are able to reestablish their self-esteem, and deal with, overcome, recover, and grow stronger. These positions offer benefits to life as a whole and, therefore, provide a better condition for an inner organization toward self-care.

I try to sow my own destiny... I didn't feel like doing anything, today I am back in school and enjoying it... I feel much more valuable now than I did before $(\mathrm{I},+, 54 \mathrm{y})$.

\section{At the outpatient clinic... the rule must be obeyed}

The quality of relationships between patients and the health service and the attachment with the technical team is also noticed as a mediator of autonomy and self-esteem. In this case, these are the non-prescriptive resources that patients recognize as being the support for them to recover the self care process.

The doctor... who saw me last time... called my attention... she was right... because I was gaining weight... we talked a lot (D, o, $48 \mathrm{y})$.

Patients stated some resources that can, at some point and in a certain context, promote treatment autonomy. Those resources include the trust relationships developed through dialogue, the creation of collective areas for exchanging experiences, in addition to a position of welcoming and being open to listening.

In the group... one motivates the other. It is easier... they take care of us... The nutritionist, the psychologist, social worker, the physician... they are ready to help (E,,$+53 \mathrm{y})$.

However, other feelings that permeate the relationships between patients and the health team were also stated. One of them is the dissatisfaction with the rules and goals established unilaterally, which can consist of a source of isolation and loss of motivation.

At the outpatient clinic... rules must be obeyed... After I stop losing weight I quit... I stayed alone at home... lonely... "attacking" problems and ended up gaining weight again. (silence). That gets you removed from the surgery waiting line $(\mathrm{E}, \mathrm{O}, 53 \mathrm{y})$.

The health care process performed by part of the professionals does not always take patient subjectivity into consideration, which is expressed to reveal different meanings. Some patients reported lack of understanding and feel dissatisfied regarding the team, and saw themselves as victims of failing the treatment.

I can't lose weight... It's not because of eating... On the contrary, I've gotten really sick for not eating... Nobody believes it... I feel like a liar $(\mathrm{C}, 9,45 \mathrm{y})$.

This experience can be understood as a way of expressing, once again, the difficulty of taking responsibility for the self care process. However, feelings of dissatisfaction or misunderstanding toward the health team should be welcomed, so that it is possible to understand their meanings with the purpose of making the support network stronger and developing the patients' ability of assuming the leading role, necessary to manage the process of becoming chronically ill.

\section{DISCUSSION}

Consistent self-esteem is one of the intrapsychic resources that help patients live, with an active position, the process of becoming chronically ill. The ability to act and become motivated for self care promotes well-being and indicates the possibility of controlling MS symptoms ${ }^{(19-20)}$. 
The development of self-esteem is a trigger of resilience and empowerment for individuals with health care needs. It is a resource that aims at the search for a balance between risk and protection, opposed to perfectionism, considering this balance is dynamic, dialectic. Therefore, it does not refer to simply improve patients' adhesion to treatment or seeking a perfect, standard behavior, which is an artificial, forced perfection that hinders creativity and the ability to discover new ways of living with the process of becoming ill ${ }^{(21)}$.

To promote the self-esteem of patients living with chronic illness processes means to promote the discovery of their own strengths to overcome hardships. It is a process of transferring the authority and responsibility of self care ${ }^{(20)}$.

The meanings of losing liberty, associated with the diet, evidenced in this study, were also discussed in previous studies. Sweet foods, for instance, have been identified as being the most attractive and appreciated by individuals with diabetes. When sweets acquire a meaning of prohibition and restriction to their source of everyday pleasure, they become even more attractive. This could justify the known transgression being a new source of pleasure ('the taste of the forbidden sweet') and the paradoxical effect of the $\operatorname{diet}^{(22-23)}$.

The conflict lived by patients between the process of taking responsibility for their health and the tendency to avoid that responsibility results in blaming the 'unjust situation', victimized by the condition of being ill ${ }^{(20)}$. In this way, they are unable to manage diet prescriptions and adapt them to their customs, values and beliefs, which determine their eating behaviors.

Studies show that in both acute and chronic situations these experiences of vulnerability can mean, for some people, the encouragement for making changes or at least for adaptation and personal development. Something that is insuperable for some, can represent difficulties and positive obstacles for others, and is seen as a challenge and motivation ${ }^{(21)}$.

In the same way, the patients' experiences at health services and with the professionals are particular and range according to the quality of health care practices and the intersection of subjectivities. A bond of trust permeated by dialogue and exchanging experiences, can, for instance, help to develop autonomy to thinking and act with creativity.

\section{REFERENCES}

1. Alberti KG, Eckel RH, Grundy SM, Zimmet PZ, Cleeman JI, Donato KA, et al. Harmonizing the metabolic syndrome: A joint interim statement of the International Diabetes Federation Task Force on Epidemiology and Prevention; National Heart, Lung, and Blood Institute; American Heart Association; World Heart Federation; International
On the other hand, excluding rules and treatment goals that are established unilaterally make the relationships fragile and can promote isolation among patients who are unable to achieve the idealized behavior ${ }^{(9)}$. When those people face exclusion due to the rules imposed, they reaffirm their distress and present themselves as victimized by the lack of understanding from their caregivers.

\section{CONCLUSION}

People who report being victimized by the circumstances suggest fragileness in their autonomy for self care and assume a passive and motionless position, showing no possibility of making changes and dealing with everyday difficulties. These patients focus on suffering, physical limitations and on the feeling of self-pity, which keeps them from taking responsibility for promoting their own health.

Subjects regret losing the pleasure and liberty of eating, and claim being victimized by distress. However, some patients live this experience as an opportunity to develop their cooking skills, mediated by affection and the desire to achieve the potential of adapting to the limitations imposed by the chronic disorders. The support and admiration from family and friends in their social living, generated by commensality, promote the patients' potential for self care.

Health care professionals should be aware about the universe of meanings that diets and foods have for patient. When recognized, the meanings help understand the connotation that the disease has in these people's lives

Active listening and welcoming subjectivities that occur in health care practices are essential for professionals that give orientations for patients with chronic metabolic disorders. Foods, especially, have specific meanings, and social, psychological and cultural dimensions, which determine that eating behaviors are established with different meanings in the health disease process.

This study has implications for clinical practice, due to the identification of some resources, based on the patients' view, to focus care/assistance actions on the development of autonomy in managing eating and self care in the process of becoming chronically ill due to metabolic disorders. It is mandatory for health professionals to focus on the individual, to be able to notice, in the patients themselves and in their socio-cultural context, the instruments to establish behavior changes.

Atherosclerosis Society; and International Association for the Study of Obesity. Circulation. 2009; 120(16):1640-5.

2. Geloneze B. Síndrome metabólica: mito ou realidade? Arq Bras Endocrinol Metabol. 2006; 50(3):409-11.

3. Opie LH. Metabolic syndrome. Circulation. 2007; 115(3):e32-5. 4. Velásquez-Meléndez G, Gazzinelli A, Côrrea-Oliveira R, 
Pimenta AM, Kac G. Prevalence of metabolic syndrome in a rural area of Brazil. São Paulo Med J. 2007; 125(3):155-62.

5. Beasley JW, Starfield B, van Weel C, Rosser WW, Haq CL . Global health and primary care research. J Am Board Fam Med. 2007; 20(6):518-26.

6. Smith TW, Orleans CT, Jenkins CD. Prevention and health promotion: decades of progress, new challenges, and an emerging agenda. Health Psychol. 2004; 23(2):126-31.

7. Ribeiro MA, Martins MA, Carvalho CR. The role of physician counseling in improving adherence to physical activity among the general population. São Paulo Med J. 2007; 125(5):115-21.

8. Linck CL, Bielemann VL, de Sousa AS, Lange C. The chronic patient in face of falling ill and the treatment compliance. Acta Paul Enferm. 2008; 21(2):317-22.

9. Folta SC, Goldberg JP, Lichtenstein AH, Seguin R, Reed PN, Nelson ME. Factors related to cardiovascular disease risk reduction in midlife and older women: a qualitative study. Prev Chronic Dis. 2008; 5(1):A06.

10. Meetoo D. Dietary pattern of self-care among Asian and Caucasian diabetic patients. Br J Nurs. 2004;13(18):1074-8.

11. Mattos L, Cravo C. Síndrome metabólica e dieta. In: Godoy-Matos AF. Síndrome metabólica. São Paulo: Atheneu; 2005. p.303-11.

12. Sharovsky LL, Perez GH, Romano BW, Lopes HF. Psicoterapia de grupo em pacientes portadores de síndrome metabólica. Rev Soc Cardiol Estado de São Paulo. 2004; 14(4):646-51.

13. Corica F, Corsonello A, Apolone G, Mannucci E, Lucchetti $\mathrm{M}$, Bonfiglio C, et al. Metabolic syndrome, psychological status and a quality of life in obesity: the QUOVADIS Study. Int J Obes (Lond). 2008; 32(1):185-91.

14. Fontanella BJ, Campos CJ, Turato ER. Data collection in clinical-qualitative research: use of non-directed interviews with open-ended questions by health profissionals. Rev Latinoam Enferm. 2006; 14(5):812-20.

15. Turato ER. [Qualitative and quantitative methods in health: definitions, differences and research subjects]. Rev Saúde Pública. 2005; 39(3):507-14. Portuguese.

16. Turato ER, Machado AC, Silva DF, de Carvalho GM, Verderosi NR, de Souza TF. Research publications in the field of health: omission of hypotheses and presentation of common-sense conclusions. São Paulo Med J. 2006; 124(4):228-33.

17. Fontanella BJ, Rica J, Turato ER. [Saturation sampling in qualitative health research: theoretical contributions]. Cad Saúde Pública 2008; 24(1):17-24. Portuguese.

18. Schiller P. As psicossomáticas.In: Ferraz FC, Volich RM, Ranña, W organizadores. Piscossoma: psicossomática psicoanalítica. São Paulo: Casa do Psicólogo; 2003p. 27-31.

19. Torsch VL, Ma GX. Cross-cultural comparasion of healh perceptions, concerns, and a coping strategies among Asian and Pacific Islander American elders. Qual Health Res. 2000; 10(4):471-89.

20. Perez GH, Romano BW. Comportamento alimentar e síndrome metabólica: aspectos psicológicos. Rev Soc Cardiol Estado de São Paulo. 2004; 14(4):544-50.

21. Pesce RP, Assis SG, Santos N, de Oliveira RV. Risco e proteção: em busca de um equilíbrio promotor de resiliência. Psicol Teor Pesqui. 2004; 20(2):135-43.

22. Garcia RW. [Representations on food intake and its implications in nutritional investigations: qualitative study with subjects submitted to dietary prescriptions]. Rev Nutr. 2004; 17(1):15-28. Portuguese.

23. Péres DS, Franco LJ, dos Santos MA. [Eating behavior among type 2 diabetes women] Rev Saúde Pública. 2006; 40(2):310-7. Portuguese. 